International Journal of Earth Sciences

Volume 96, Number 1 / February, 2007; Pages 103-120

http://dx.doi.org/10.1007/s00531-005-0496-x

(c2006 Springer Science+Business Media
Archimer, archive institutionnelle de l'Ifremer http://www.ifremer.fr/docelec/

\title{
Thérèse Mound: a case study of coral bank development in the Belgica Mound Province, Porcupine Seabight
}

\author{
Ben De $\mathrm{Mol}^{1,2,{ }^{*}}$ Max Kozachenko ${ }^{3}$, Andy Wheeler ${ }^{4}$, Hugo Alvares ${ }^{5}$, \\ Jean-Pierre Henriet ${ }^{1}$ and Karine Olu-Le Roy ${ }^{6}$
}

(1) Renard Centre of Marine Geology, Ghent University, Krijgslaan, 281 S8, 9000 Gent, Belgium

(2) GRC Geociències Marines, Universitat de Barcelona, Campus de Pedralbes, 08028 Barcelona, Spain

(3) Coastal\& Marine Resources Centre, Environment Research Institute, University College Cork, Cork, Ireland

(4) Department of Geology and Environment Research Institute, University College Cork, Cork, Ireland

(5) School of Ocean Sciences, University of North Wales, Bangor, Wales, UK

(6) Département Environnement Profond, IFREMER, Technopole de Brest-Iroise, BP 70, 29280

Plouzane, France

*: Corresponding author : bendemol@ub.edu

\begin{abstract}
High-resolution seismic profiles, swath bathymetry, side-scan sonar data and video imageries are analysed in this detailed study of five carbonate mounds from the Belgica mound province with special emphasis on the well-surveyed Thérèse Mound. The selected mounds are located in the deepest part of the Belgica mound province at water depths of $950 \mathrm{~m}$. Seismic data illustrate that the underlying geology is characterised by drift sedimentation in a general northerly flowing current regime. Sigmoidal sediment bodies create local slope breaks on the most recent local erosional surface, which act as the mound base. No preferential mound substratum is observed, neither is there any indication for deep geological controls on coral bank development. Seismic evidence suggests that the start-up of the coral bank development was shortly after a major erosional event of Late Pliocene-Quaternary age. The coral bank geometry has been clearly affected by the local topography of this erosional base and the prevailing current regime. The summits of the coral banks are relatively flat and the flanks are steepest on their upper slopes. Deposition of the encased drift sequence has been influenced by the coral bank topography. Sediment waves are formed besides the coral banks and are the most pronounced bedforms. These seabed structures are probably induced by bottom current up to $1 \mathrm{~m} / \mathrm{s}$. Large sediment waves are colonised by living corals and might represent the initial phase of coral bank development. The biological facies distribution of the coral banks illustrate a living coral cap on the summit and upper slope and a decline of living coral populations toward the lower flanks. The data suggest that the development of the coral banks in this area is clearly an interaction between biological growth processes and drift deposition both influenced by the local topography and current regime.
\end{abstract}

Keywords Thérèse Mound - Belgica mound province - coral banks - Porcupine Seabight - Lophelia pertusa - Cold-water corals - Carbonate mounds 


\title{
Original paper
}

\section{Thérèse Mound: a case study of coral bank development in the Belgica Mound Province, Porcupine Seabight}

\section{Ben De Mol (®) • Max Kozachenko • Andy Wheeler · Hugo Alvares • Jean-Pierre Henriet • Karine Olu-Le Roy}

B. De Mol · J.-P. Henriet

Renard Centre of Marine Geology, Ghent University, Krijgslaan, 281 S8, 9000 Gent, Belgium

B. De Mol

GRC Geociències Marines, Universitat de Barcelona, Campus de Pedralbes, 08028 Barcelona, Spain

M. Kozachenko

Coastal\& Marine Resources Centre, Environment Research Institute, University College Cork, Cork, Ireland

\author{
A. Wheeler \\ Department of Geology and Environment Research Institute, University College Cork, Cork, \\ Ireland \\ H. Alvares \\ School of Ocean Sciences, University of North Wales, Bangor, Wales, UK \\ K. Olu-Le Roy \\ Département Environnement Profond, IFREMER, Technopole de Brest-Iroise, BP 70, 29280 \\ Plouzane, France
}

B. De Mol

E-mail: bendemol@ub.edu

Received: 18 February 2005 / Accepted: 15 March 2005

\begin{abstract}
High-resolution seismic profiles, swath bathymetry, side-scan sonar data and video imageries are analysed in this detailed study of five carbonate mounds from the Belgica mound province with special emphasis on the well-surveyed Thérèse Mound. The selected mounds are located in the deepest part of the Belgica mound province at water depths of $950 \mathrm{~m}$. Seismic data illustrate that the underlying geology is characterised by drift sedimentation in a general northerly
\end{abstract}


flowing current regime. Sigmoidal sediment bodies create local slope breaks on the most recent local erosional surface, which act as the mound base. No preferential mound substratum is observed, neither is there any indication for deep geological controls on coral bank development. Seismic evidence suggests that the start-up of the coral bank development was shortly after a major erosional event of Late Pliocene-Quaternary age. The coral bank geometry has been clearly affected by the local topography of this erosional base and the prevailing current regime. The summits of the coral banks are relatively flat and the flanks are steepest on their upper slopes. Deposition of the encased drift sequence has been influenced by the coral bank topography. Sediment waves are formed besides the coral banks and are the most pronounced bedforms. These seabed structures are probably induced by bottom current up to $1 \mathrm{~m} / \mathrm{s}$. Large sediment waves are colonised by living corals and might represent the initial phase of coral bank development. The biological facies distribution of the coral banks illustrate a living coral cap on the summit and upper slope and a decline of living coral populations toward the lower flanks. The data suggest that the development of the coral banks in this area is clearly an interaction between biological growth processes and drift deposition both influenced by the local topography and current regime.

Keywords Thérèse Mound $\cdot$ Belgica mound province $\cdot$ coral banks $\cdot$ Porcupine Seabight $\cdot$ Lophelia pertusa $\cdot$ Cold-water corals $\cdot$ Carbonate mounds

\section{Introduction}

The Porcupine Seabight is well known for the occurrences of seabed mounds occurring in well-defined provinces (e.g. Henriet et al. 1998; De Mol et al. 2002). These provinces are distinguished by mound morphology and their geographic location as discussed in detail by De Mol et al. (2002). This paper focus on a cluster of five mounds, which includes the intensely surveyed Thérèse Mound, which are part of the Belgica mound province (Henriet et al. 1998; De Mol et al. 2002; Van Rooij et al. 2003). The Thérèse Mound was discovered during a high-resolution seismic survey in 1998 and is characterised by an acoustic character unlike the other Belgica Mounds surveyed (Fig. 1). The mound surface is characterised by poor bottom lock with no clear lineation of the summit in comparison with the surrounding mounds. These observations suggest that the mound might be biologically (e.g. covered by dense coral growth) or geologically (e.g. composed of soft sediments as a result of fluid escape) more "active" and be a potential site to study the relation between fluid migration and coral bank development (Henriet et al. 1999). Based 
on the initial interpretation, Thérèse Mound was selected as a special target site to study the present processes involved in mound development in the EU 5th framework projects GEOMOUND, ECOMOUND and ACES. This paper focus on the subsequent results of high-resolution seismic, side-scan sonar, subsurface coring and ROV surveys undertaken to study contemporary mound and near-mound processes, the development of selected mounds and give insights into the general evolution of present deep-water coral constructions in the NE Atlantic.

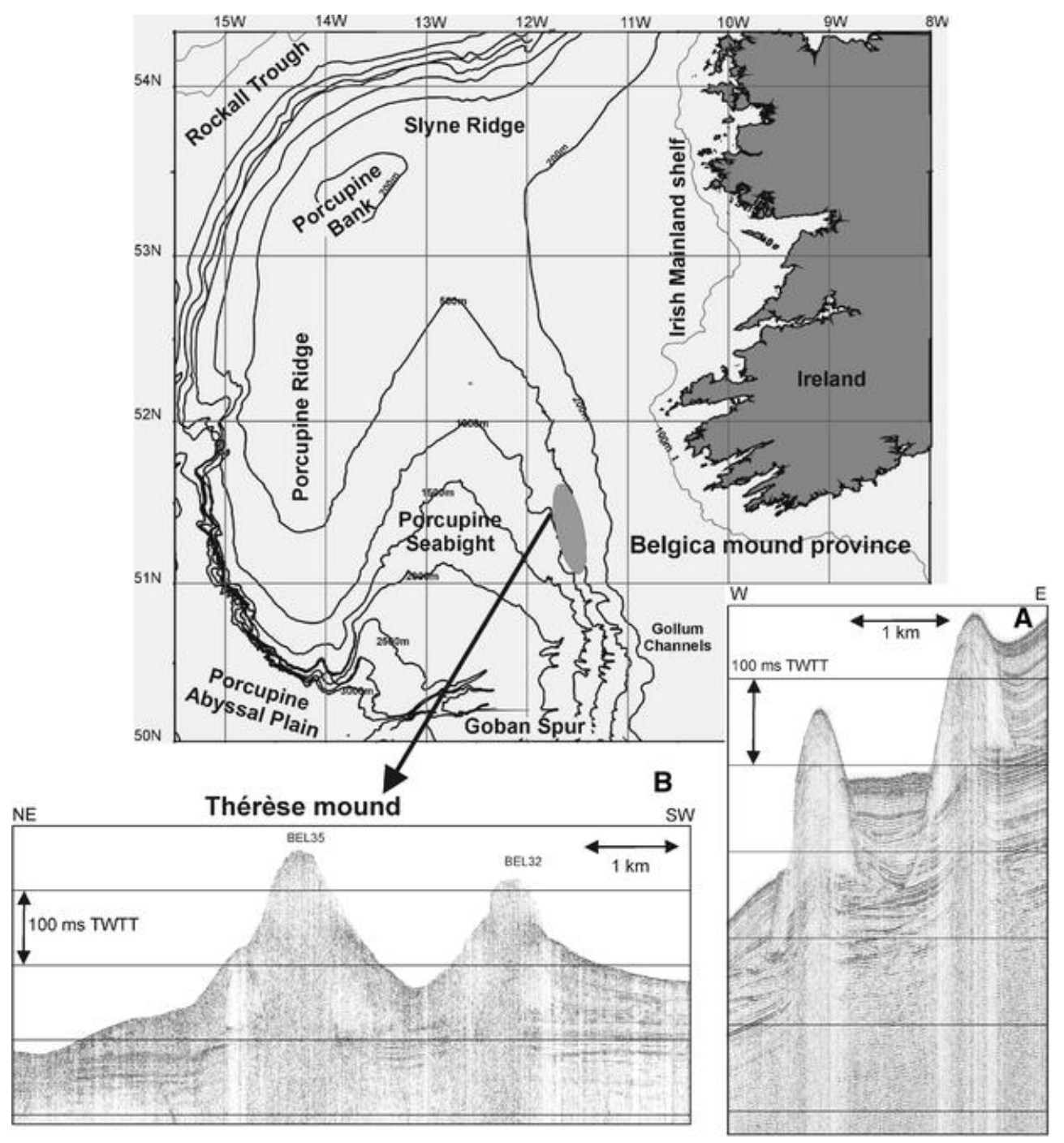

Fig. 1 Location map of the Belgica mound province. a Typical E-W orientated seismic profile of the Belgica mound province. b Seismic profile of Thérèse mound (BEL35) and BEL32, are characterised by a poor bottom lock, suggesting that the mound might be biologically or geologically more active than other Belgica Mounds 


\section{Belgica mound province}

The Belgica mound province is situated on the eastern flank of the Porcupine Seabight (Irish continental slope), between $51^{\circ} 0^{\prime} \mathrm{N}-51^{\circ} 36^{\prime} \mathrm{N}$ and $11^{\circ} 30^{\prime} \mathrm{W}-11^{\circ} 48^{\prime} \mathrm{W}$ in water depths ranging from $550 \mathrm{~m}$ to $1,025 \mathrm{~m}$. This cluster of partly buried and outcropping mounds has an elongated shape with an overall length of $45 \mathrm{~km}$ and a maximum width of $10 \mathrm{~km}$ (Fig. 1). The mound structures are associated with cold- or deep-water corals. The occurrence of high concentrations of cold-water corals (e.g. Madrepora sp. and Lophelia pertusa) on the eastern continental slope of the Porcupine Basin have been described by Thomson (1873) and Le Danois (1948) although neither recognised the association with mounds (coral mounds or banks). In total, 64 mounds are now recognised of which 47 are above the seabed and 17 are buried. Buried mounds are defined as mounds of which the crest is covered by sediment (De Mol 2002). All mounds recorded during the seismic surveys and multibeam swath bathymetry survey have been organised in a database and are numbered from the south to the north (De Mol 2002).

The general bathymetric map of the Belgica mound province (Beyer et al. 2000, 2003) shows that the province is characterised by $\mathrm{N}-\mathrm{S}$ orientated, along-slope channels and downslope orientated turbidite channels in this part of the Irish continental margin (Fig. 2) (Van Rooij et al. 2003). The background surface slope in the mound province is about $5^{\circ}$. Mounds in the $750 \mathrm{~m}$ water depth range are located in a relatively steep part of the margin. Further to the west and downslope, a second range of smaller mounds, including the Thérèse Mound, is located around $950 \mathrm{~m}$ water depth in a less steep zone $\left(2-3^{\circ}\right)$ and closer to a large N-S trending channel (Fig. 2) (De Mol 2002; Van Rooij et al. 2003). Mounds located on the lower flanks of the NS-oriented channel are less complex in geometry than those in the upper range. 


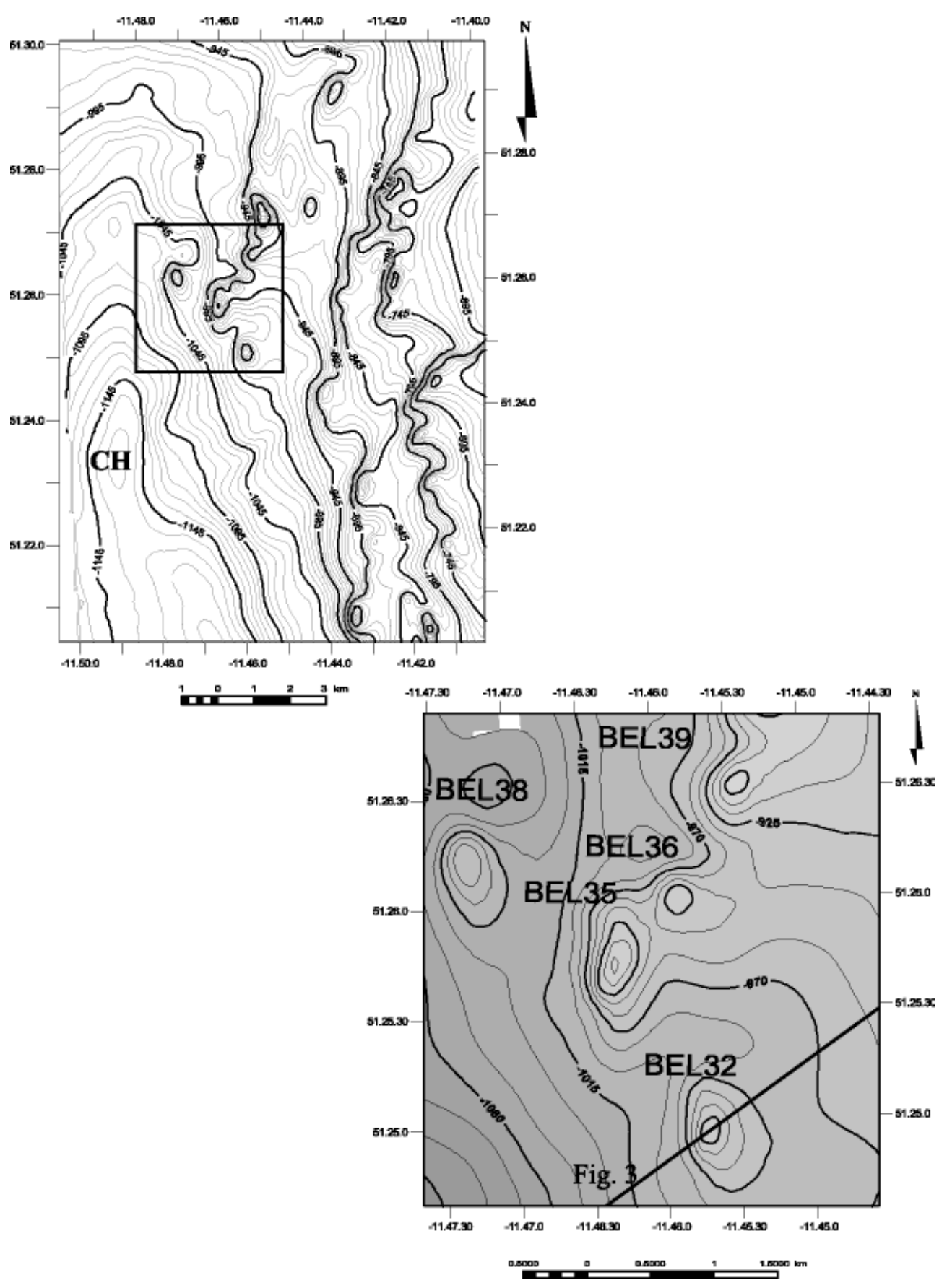

Fig. 2 Location map of the study area in the general bathymetry of the Belgica mound province. The five selected mounds are flanked by turbidite channels and are limited to the west by a NS oriented channel $\mathrm{CH}$

The mounds are enclosed in drift sediments of Quaternary age (Van Rooij et al. 2003). Near the mounds, the sediment drift thickness is reduced to form moats around most mounds. The drift architecture and seismic reflectors in this drift sequence suggest that the mounds have acted as obstacles in the current regime during deposition. It is believed that the mounds started to develop shortly after the major erosional event that created the mound base and developed quickly, to almost their full dimensions, before drift sedimentation started in earnest (Van Rooij et al. 2003). The inferred age for the mound base reflector is Late Pliocene to Early Quaternary. The eastern 
flanks of the mounds are typically draped by sediments, which are pounded between the mound and the local seabed slope (De Mol 2002; De Mol et al. 2002; Van Rooij et al. 2003).

\section{Thérèse Mound and other nearby mounds}

This paper focuses on a cluster of five neighbouring mounds: The Thérèse Mound (BEL35), BEL32, BEL36, BEL38 and BEL39 (Fig. 2). These mounds are located in a relatively flat area close to a N-S trending channel $(\mathrm{CH})$ in the central western part of the Belgica mound province (Fig. 1). The water depth of this area is about $950 \mathrm{~m}$.

\section{Data}

The Thérèse Mound area has been surveyed by high-resolution sparker seismic, side-scan sonar and ROV. The detailed high-resolution seismic sparker grid consists of $153 \mathrm{~km}$ of seismic lines covering an area of $15 \mathrm{~km}^{2}$ with a $10.2 \mathrm{~km} / \mathrm{km}^{2}$ line density and a spacing of $200 \mathrm{~m}$ collected during several cruises. The vertical resolution of the seismic profiles is $0.5 \mathrm{~m}$ for a typical frequency of $600 \pm 50 \mathrm{~Hz}$ or a wavelength of $2.8 \mathrm{~m}$. The horizontal resolution along the seismic line is $37 \pm 7 \mathrm{~m}$. This seismic grid facilitates a detailed study of mound geometry and the underlying geology of the mounds cluster. Side-scan sonar coverage was collected with a GeoAcoustic dual frequency $(100 / 410 \mathrm{kHz})$ side-scan sonar system operated at $100 \mathrm{kHz}$ with a swathe width of $600 \mathrm{~m}$ (Wheeler et al. 2000, 2001). The accuracy of image navigation is $\pm 50 \mathrm{~m}$. Side-scan sonar data were processed at the Southampton Oceanography Centre using the PRISM sonar software system (Le Bas and Huhnerbach 1999, Wheeler et al. 2000; Kozachenko et al. 2002). The interpretation of the side-scan sonar backscatter is aided by draping over multibeam bathymetry (Beyer et al. 2000; 2003). The side-scan mosaic was ground-truthed with a total of $35 \mathrm{~h}$ of detailed ROV Victor (CARACOLE cruise) and SHRIMP (Discovery 248 cruise) video observations and sediment sampling (Bett et al. 2001; Olu-Le Roy et al. 2002).

\section{Results and interpretation}

\section{Bathymetric expression of the mounds}

With only one exception, BEL36, which has an almost circular mound shape, the mounds expressed on the bathymetric map are elongated a more or less $\mathrm{N}-\mathrm{S}$ parallel to the $\mathrm{N}-\mathrm{S}$ channel $(\mathrm{CH}$; Fig. 2). The steepest mound flanks are facing turbidite channels in between the mounds or the along slope 
channel $(\mathrm{CH})$. The smooth flanks observed in the multibeam are mound flanks covered with sediment drift accumulating between neighbouring mounds (e.g. BEL 35 and 36) (Fig. 3). The seabed expression or morphology of the mounds seems to be clearly linked to the hydrodynamic regime, which is active in the area, concentrated in the channels and related to sediment dynamics and seabed morphology.
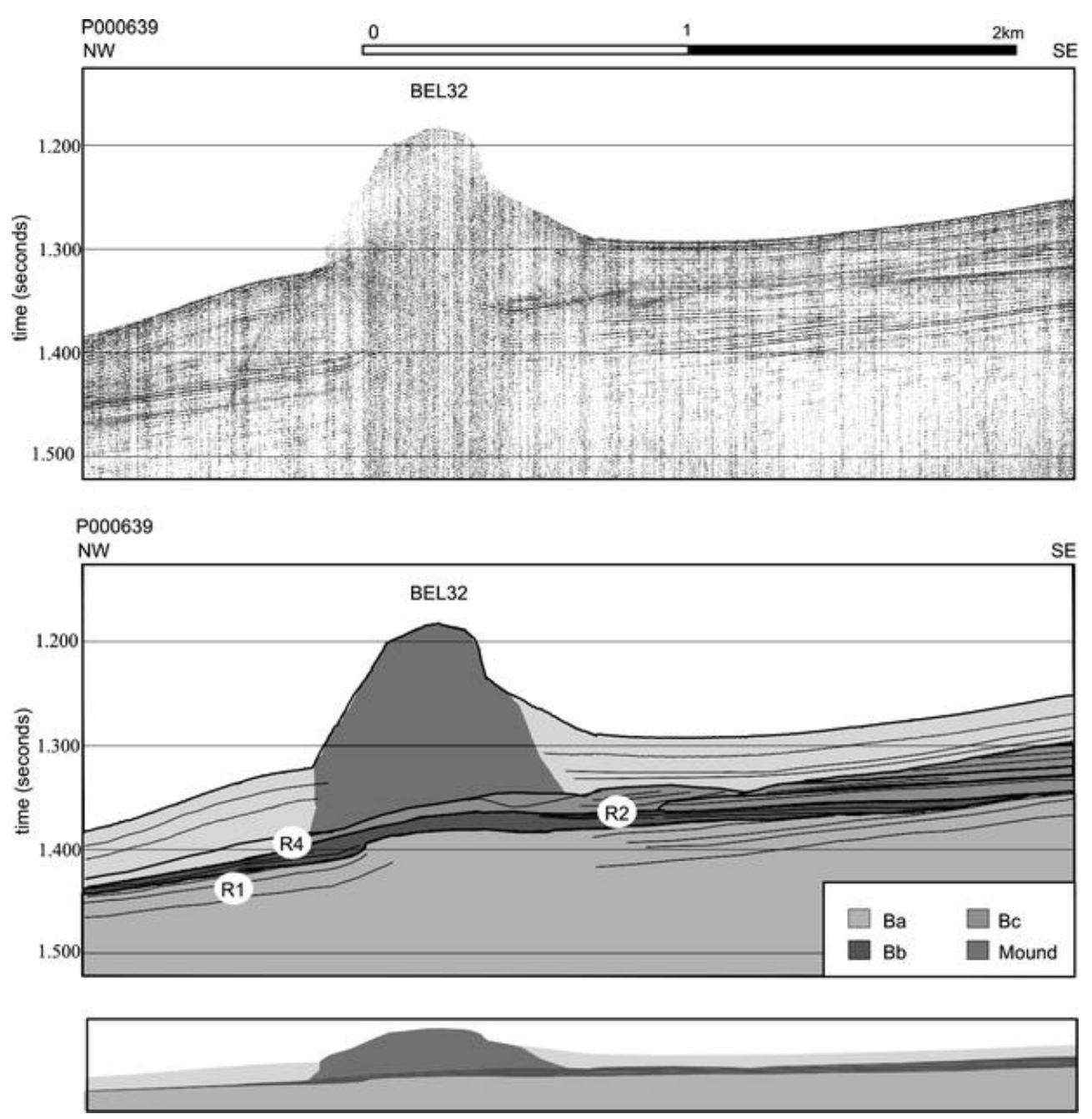

Fig. 3 Seismic profile illustrating the substratum and enclosing sediment of BEL32. The mound is located at the edge of the seismic unit Bb creating a slope break at the moundbase $(R 4)$ level. Sediments are ponded between the mounds and the slope on the eastern flank, upslope flank of the mound. The lower section of the profiles shows the seismic profile in a true scale 1:1

\section{Seismic mound facies}

The mounds appear on seismic profiles as almost acoustically transparent dome-shaped structures (Fig. 3). The mounds are bounded by diffraction hyperbolae originating at the summit of the mound. Inside the mounds, no internal reflectors have been recognised, indicating an uniform 
facies without any large acoustic impedance differences. The mound facies might also be interpreted as a loss of seismic energy due to scattering or absorption by the rough seabed and internal structure of the mound. However, an important observation is that the reflectors underneath the mounds show reduced amplitudes although the reflectors are not completely wiped out. This argues for the fact that not all the seismic energy is absorbed or dispersed inside the mound facies.

The internal structure of the coral mounds is derived from the observation of shallow cores (De Mol et al. 2002) and seismic velocity analyses (De Mol 2002). On-mound sediments contain a large amount of bio-detrital material: azooxanthellate corals of which the dominating species are Madrepora occulata Lophelia petusa and shells in a matrix of muddy sediment. The seismic facies of the coral banks is homogeneous and transparent with an estimate internal velocity between $1,850-2,000 \mathrm{~m} / \mathrm{s}$ based on velocity pull-ups of single channel seismic (De Mol 2002). This velocity suggests carbonate-rich sediment (with a velocity of 2,300 m/s) intermixed with terrigeneous material $(1,700 \mathrm{~m} / \mathrm{s})$ as groundtruthed by the surficial sediment samples.

\section{Mound morphology}

Seismic mound facies have been mapped along high-resolution seismic profiles and plotted on top of the multibeam bathymetry to investigate the mound morphology and relationships between the different types of mounds (Fig. 4). The distribution of the seismic mound facies shows a deviation from the seabed expression of the mound, based on the multibeam data. This illustrates that the mounds have a broad base in plan view at the moundbase (R4), which is now buried. 


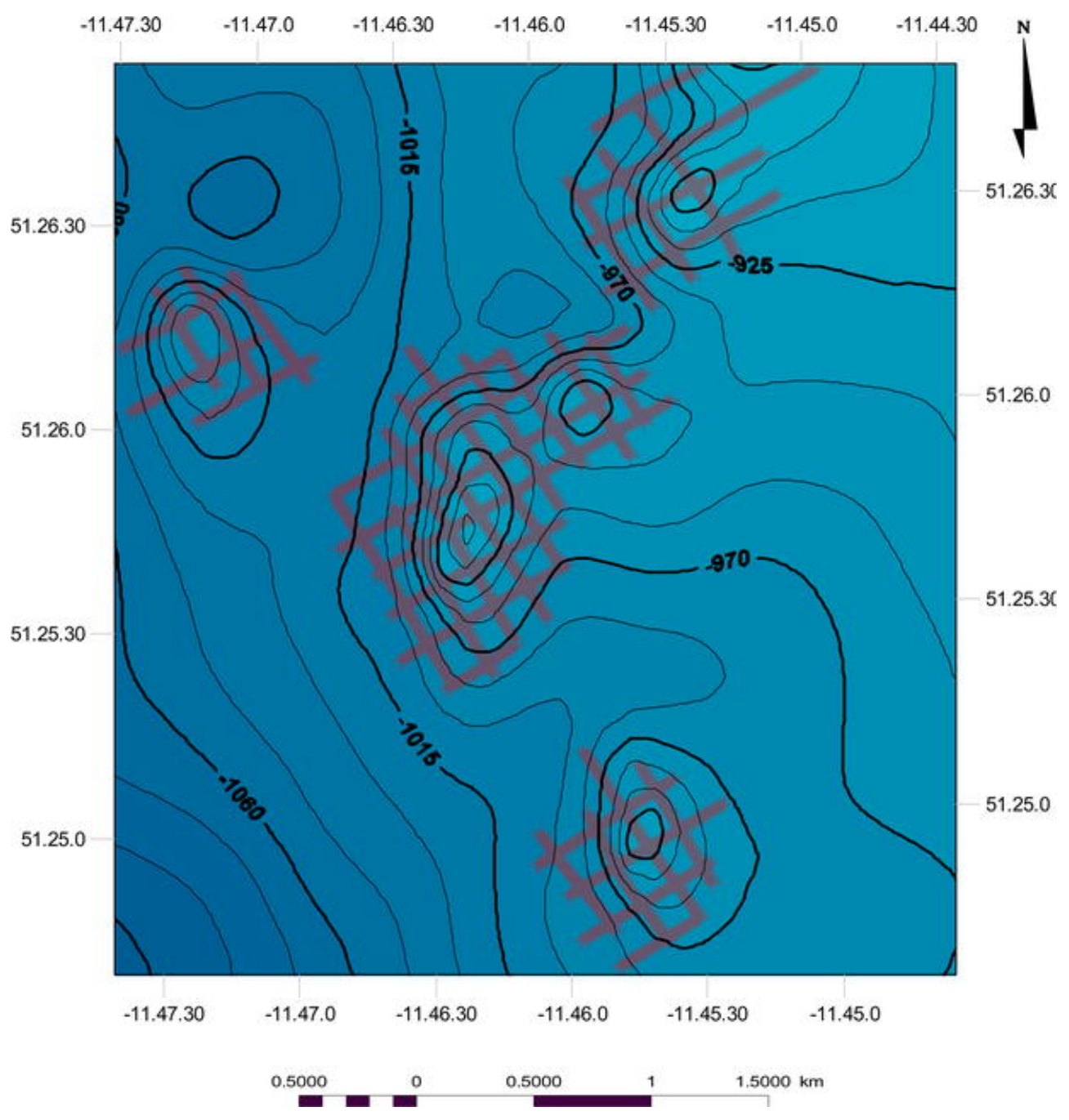

Fig. 4 Bathymetric map of the study area, showing the five studied mounds (Beyer et al. 2003). Down slope channels occur in between the mounds. The red crosses indicate the mapped seismic mound facies at the base of the mound, along the seismic profiles. This illustrates the wider and more circular shape of the moundbase than the present surface expression of the mounds. 


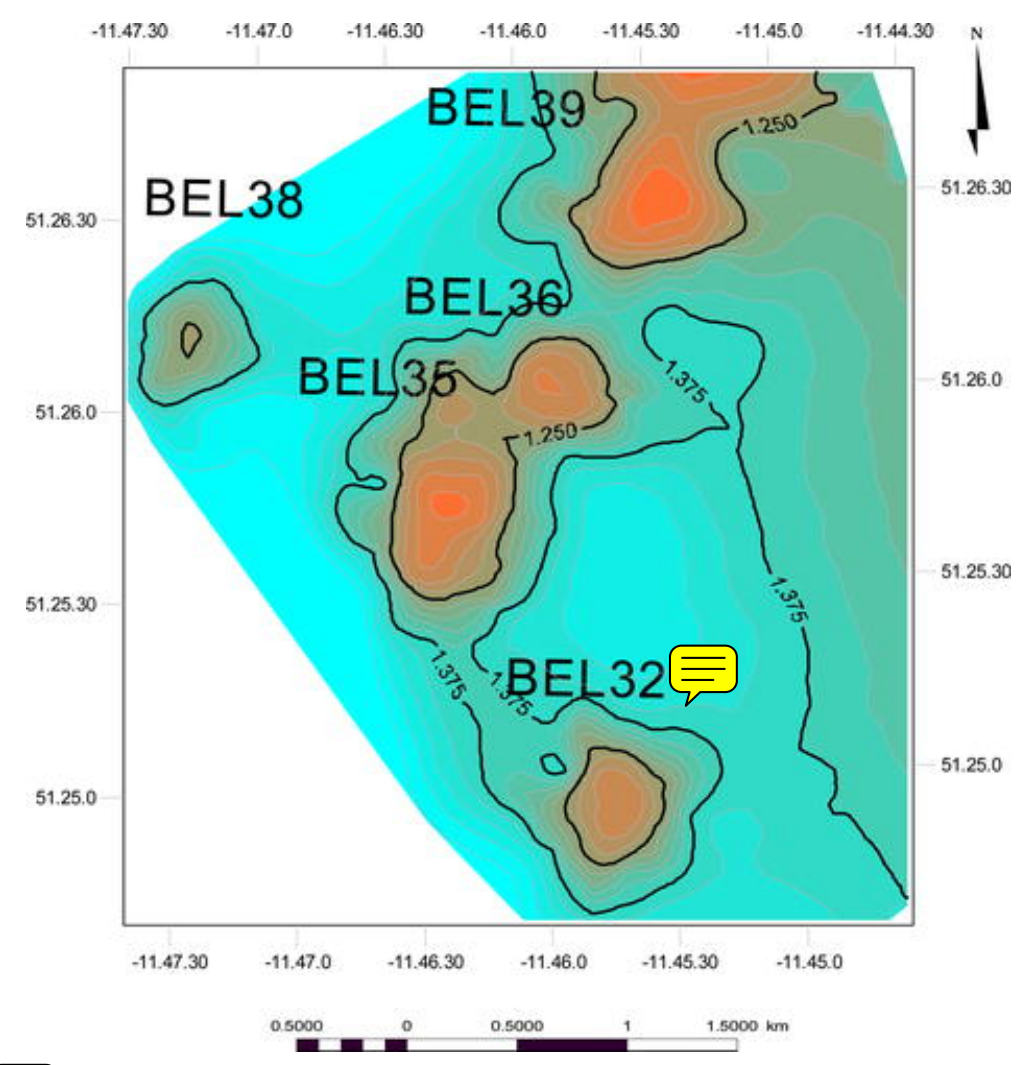

$\overline{\overline{\overline{V F}}}$. 5 Time structural (in seconds) map of the mounbase (reflector R4) and the mound facies. This map illustrates the mound morphology without enclosing sediment

The isopach map of the mound facies [from the mound base (R4) to the top of the mound facies (seabed)] has been mapped to illustrate the total mound geometry (Fig. 5).

The steepest mound flanks are oriented to the west, facing the NS channel $(\mathrm{CH})$. The mounds show an elongation in more or less a NS direction but less strong as in the seabed expression (Fig. 5).

The mounds have relatively flat summits with the steepest slopes on the upper flanks getting smoother towards the base. For each seismic profile in the area of interest, the width and height of the mounds is measured and analysed. Table 1 illustrates the dimension of the mounds recorded along the seismic profiles. The largest mound in the study area is BEL35 with a height of $210 \mathrm{~ms}$ TWT (or approximately $210 \mathrm{~m}$ ) and 1,500 m width in NS direction. All other mounds have a height of approximately $180 \mathrm{~ms}$ TWT and a longest width of about $1,000 \mathrm{~m}$.

\section{[Table 1 will appear here. See end of document.]}

Profiles crossing the mounds on their lower slopes do not show smaller bases than profiles crossing the summits. This suggests intensive lateral development of the mounds in an early phase. 


\section{Geology}

\section{Mound base}

All the mounds are initiated on one basal reflector (R4). The acoustic facies above and below R4 are different and argue for a change in the sedimentary environment after a period of erosion and non-deposition.

A palaeosurface map of the R4 reflector is shown in Fig. 6. The mound base surface is dipping to the west and the slope gradient decreases towards channel $\mathrm{CH}$. A downslope-oriented channel is also observed between the mounds BEL32 and BEL35 and can be followed higher up the slope, changing orientation close to north-south as observed in the present-day bathymetry. The mounds are clearly lined up along channel flanks and the slope break. BEL38 is located in a flat and smooth area of the R4 palaeosurface and has a more circular plan view that the other mounds (Fig. 5).

These observations suggest that the moundbase topography controlled mound development and that the mounds and the topography influenced the local oceanographic regime resulting in local and regional scouring as seen on the $\mathrm{R} 4$ palaeosurface.
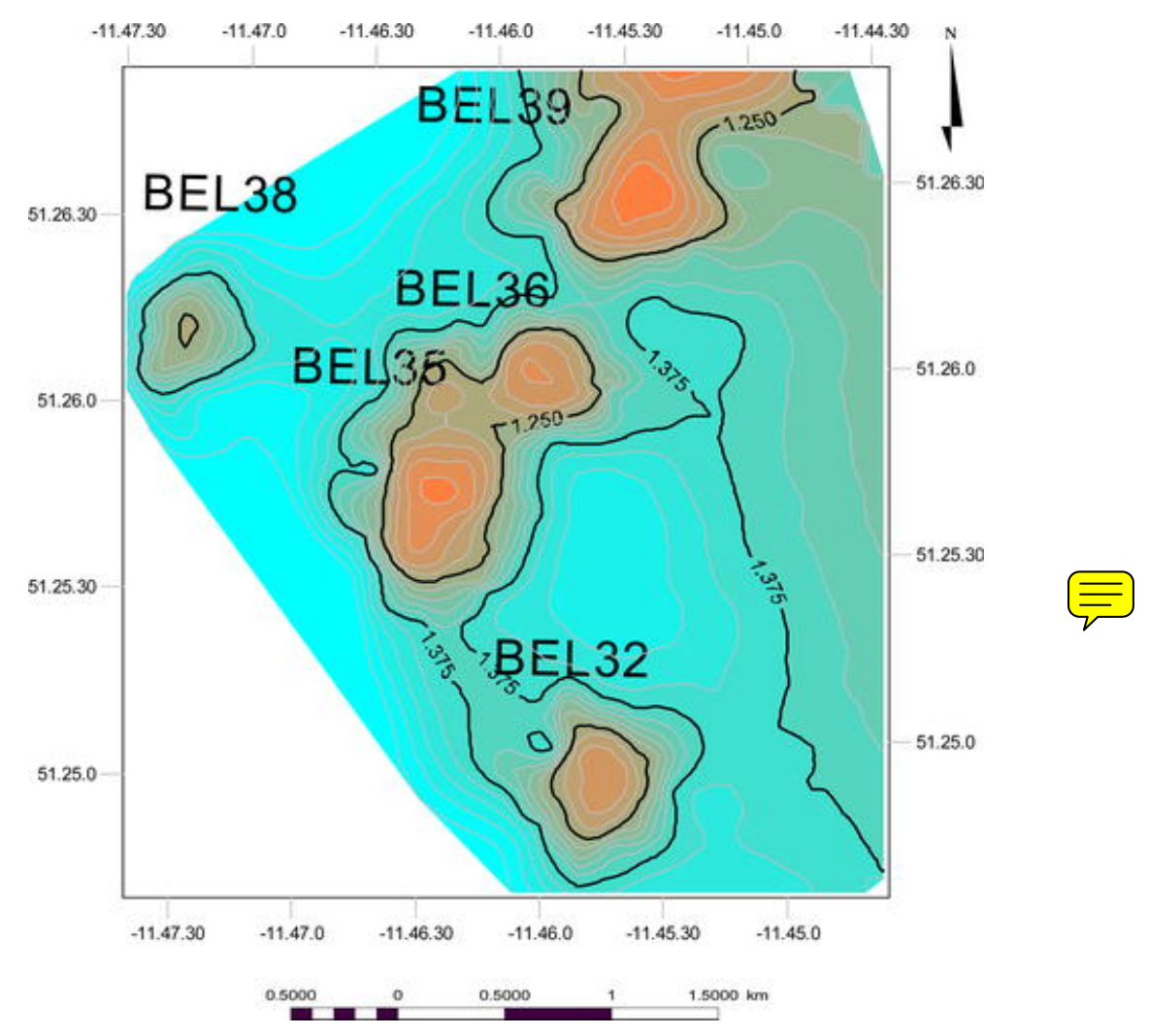

Fig. 6 Time structural map of the moundbase $(R 4)$. The surface shows that the mounds are located along channels in the moundbase 


\section{Enclosing sediment}

To study the effect of sedimentation during mound development an isopach map has been made of the enclosing sediments $(\mathrm{Be})$ between the moundbase reflector $\mathrm{R} 4$ and the seabed. The mounds are bounded by the zero contours on this isopach map (Fig. 7). The sediment thickness is largest on the eastern or upslope flanks of the mounds filling a palaeo-turbidite channel where sediments are ponded between the mounds and the slope. On the western side, the contour lines are more spread and overall sediment package is less thick, indicating a more current active environment preventing sedimentation on these more exposed mound flanks. The reflectors of this unit are parallel and onlap against the mound. In between the mounds, the reflectors' geometry changes to a wavy configuration, illustrating the dynamic current environment of the deposition.

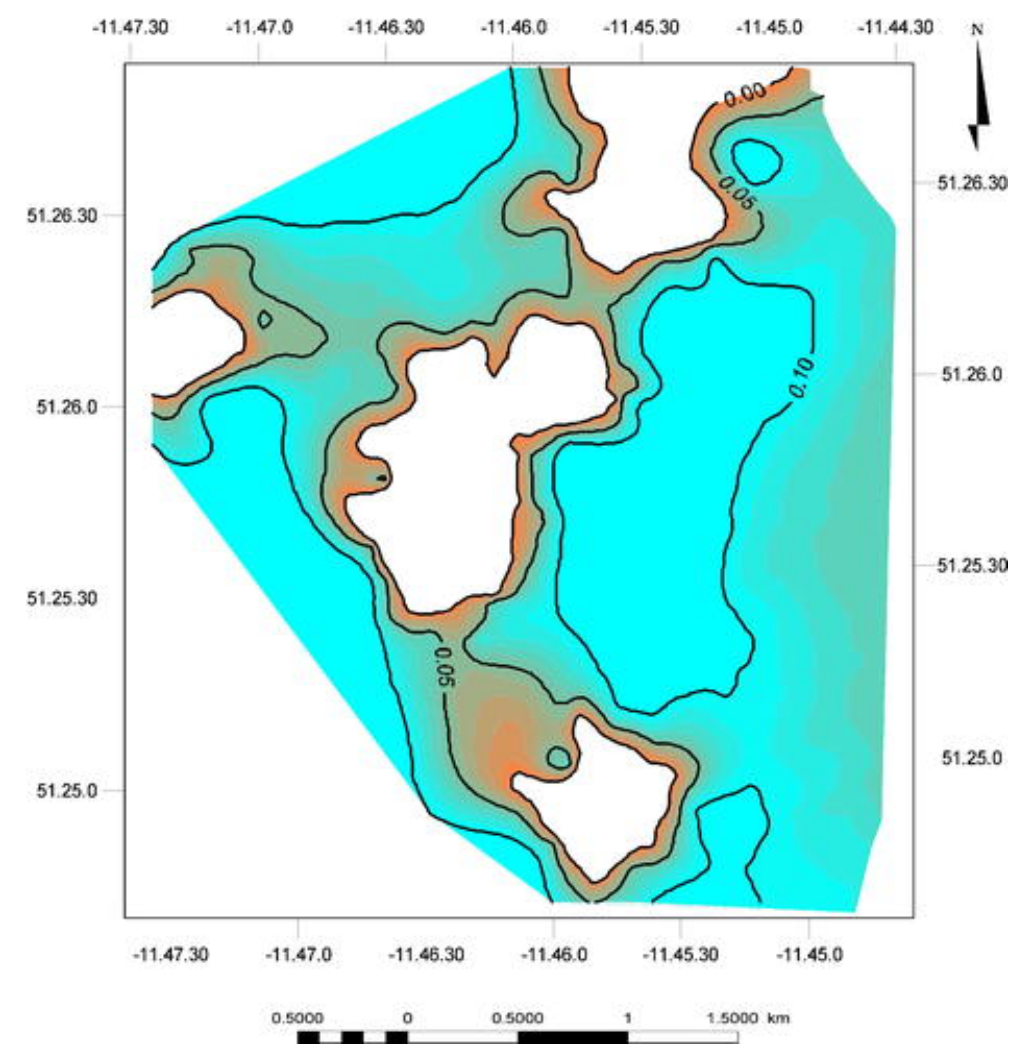

Fig. 7 Isopachmap of the enclosed sediment Be which illustrates the sediment thickness draping the mounds. The zero contour represents the area of the mound at the moundbase reflector R4 . The seismic unit is thickest in the channels observed on the structural map of R4. On the eastern and upslope flanks the mounds are draped with a thick sediment cover

\section{Substratum}

The substratum and underlying geology of the mounds are studied here to evaluate a possible deep geological control on the development of the mounds as suggested in Henriet et al. $(1998,2001)$ 
and to appraise the environmental changes occurring before and after mound initiation at R4. The different seismic units are named with a capital B to indicate the Belgica mound province and a small character for the succeeded units (Fig. 3). All recognised units are bounded by high amplitude reflectors truncating the unit and the internal reflectors. $\mathrm{R} 4$ is the most recent unconformity truncating several units and is interpreted as the moundbase.

The seismic unit $\mathrm{Ba}$ is characterised by sub-parallel continuous reflectors with moderated to low amplitudes dipping to the west and showing a wavy pattern in NS directed profiles. Unit Bb features high amplitude reflectors with a high lateral continuity. This unit forms the substratum for all the mounds (BEL32, 35, 36 39), with the exception of BEL38 in this study. At this location, unit $\mathrm{Bb}$ is characterised by sigmoidal reflectors on the NS profiles and hummocky to wavy sub-parallel reflectors on the EW profiles (Fig. 8). On the NS profiles, the reflectors are downlapping to the north onto the erosive reflector R1, or on smaller local erosional surfaces. The facies geometry changes depending on the location on the slope. The mounds seem to be located at the outer limits of this facies $\mathrm{Bb}$, which is truncated by the last erosive event indicated by $\mathrm{R} 4$, creating a break in the slope of the mound base. Unit Bc contains a second set of sigmoidal reflectors (Fig. 3) and shows an alternation of high and low amplitude reflectors with a high continuity. The unit is spatially restricted by a truncation by R4 and in the lower part by downlap on R2. In general the Belgica Mounds are not exclusively related to seismic unit $\mathrm{Bb}$, but also root on $\mathrm{Ba}$ and $\mathrm{Bc}$. Other studies related the occurrence of the Belgica Mounds to erosional scars related to the outcrop of certain seismic facies at the moundbase level, as is the case here (De Mol et al. 2002; De Mol 2002; Van Rooij et al. 2003). 


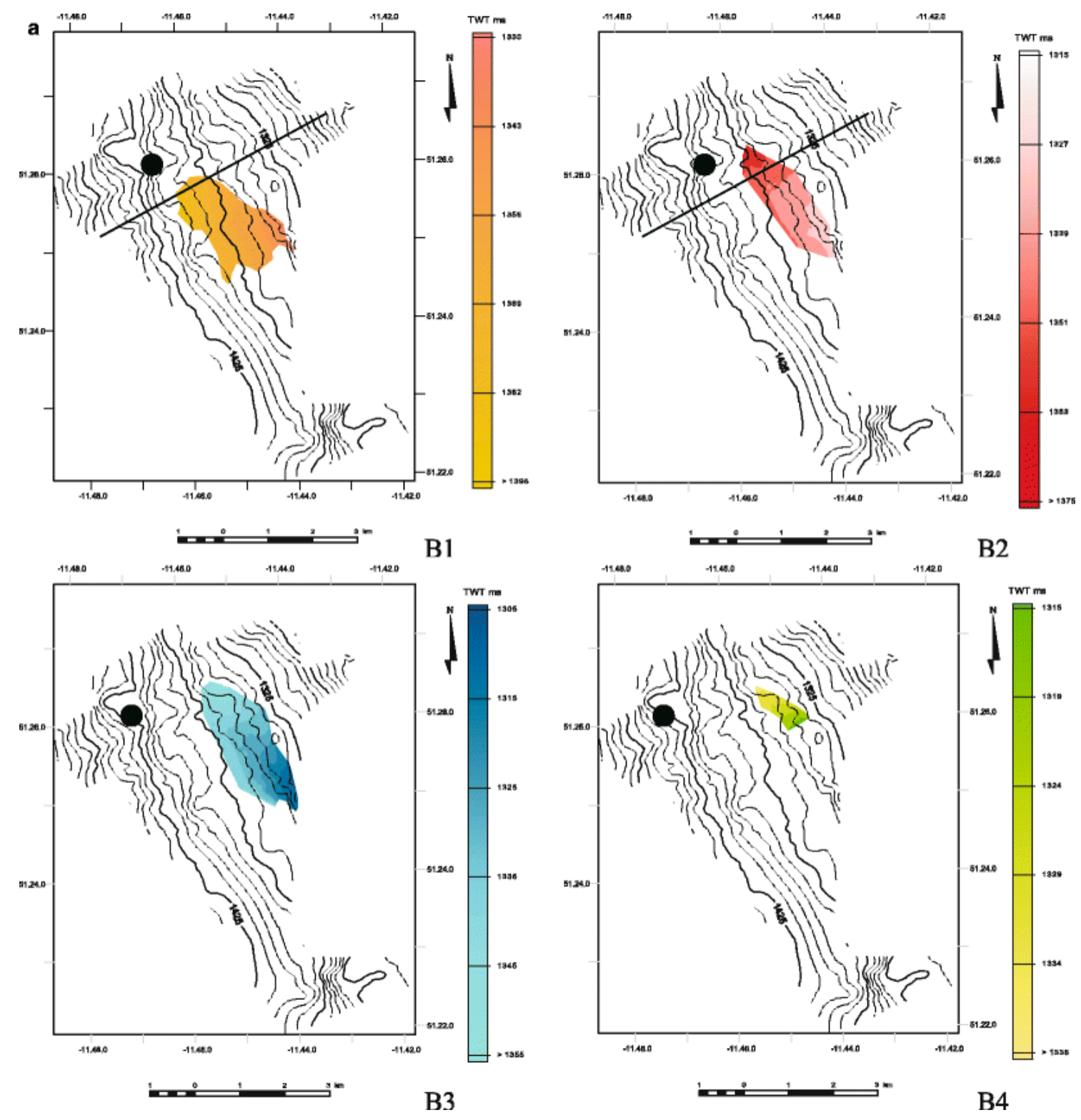




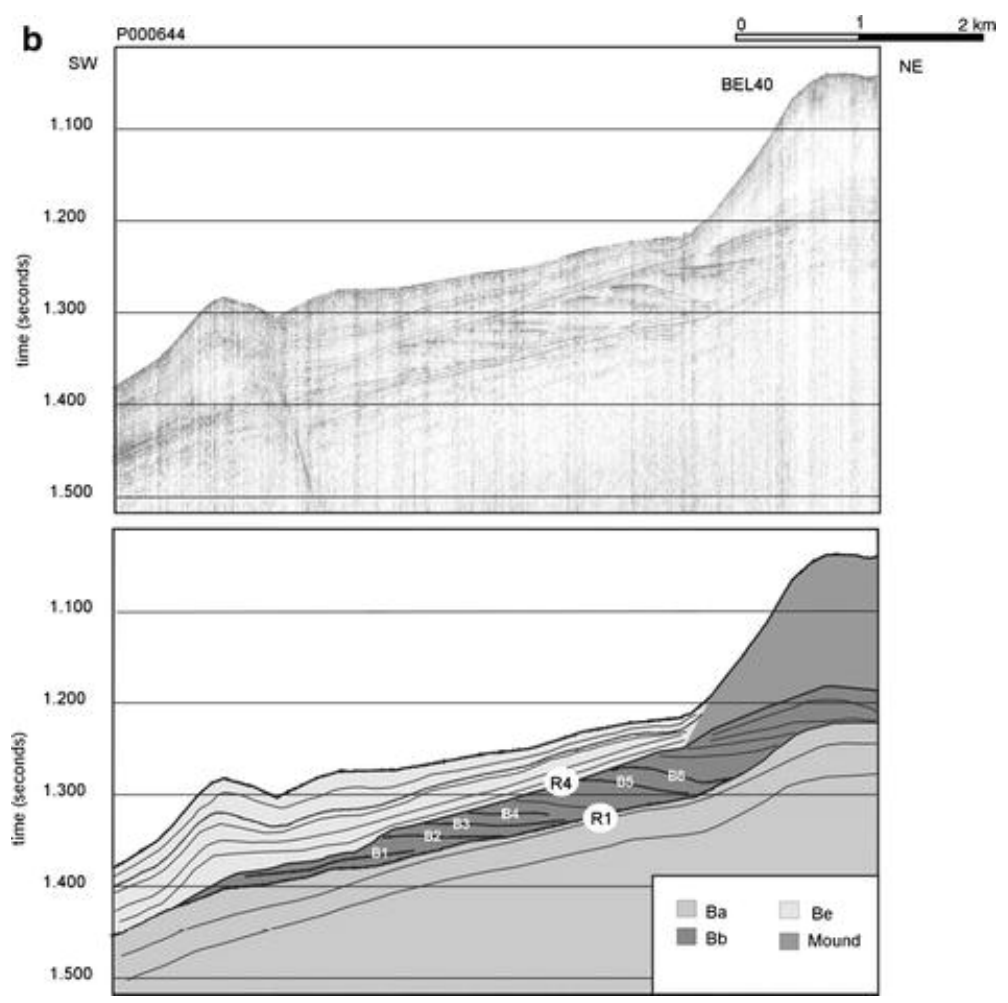

Fig. 8 a Time structural maps of respectively reflectors B1, B2, B3, B4 as defined on profile P000644 (Fig. $8 \mathrm{~b}$ ) plotted on top of the time structural map of reflector R2 or the base of facies $\mathrm{Bb}$. This set of time structural maps shows the upslope and northward migration of the sigmoidal bodies of facies Bb. Profile P000644 is indieating on the maps and the dot represents the location of Thérèse mound

\section{Migration of sigmoidal reflectors in $\mathrm{Bb}$}

Seismic unit $\mathrm{Bb}$, forms the mound substratum in most of this area, will be discussed in more details. The general geometry of the sigmoidal forms in facies Bb suggests a northward and upslope migration of the sediment. The dense seismic grid made it possible to map four internal reflectors with a sigmoidal geometry (B1, B2, B3 and B4) and two additional reflectors, which are only seen in the most upslope part of this dense grid (B5 and B6) (Fig. 8) (Galanes-Alvarez 2001).

The time structural maps of the reflectors illustrate the lateral extension of the individual bodies (Fig. 8). The sigmoidal bodies are elongated in the NS direction and are 2,700, 3,300 and 3,600-m long respectively. In the EW direction, the bodies are relatively narrow between 1,700 $\mathrm{m}$ for B1 and $1,000 \mathrm{~m}$ for B2. The bodies thin to the east or upslope and to the north. The sigmoidal bodies migrate relative against each other upslope, (about 500-600 m) and northward (about 700 and $300 \mathrm{~m})$.

The migration and distribution of this unit illustrates that the palaeo-sedimentological environment allowed a fast drift of sediment, creating sediment bodies with a sigmoidal internal 
geometry. The sediment bodies have been formed initially in the deepest part of the furrow flank and shifted to the north and upslope. This drift deposition is most probably initiated by north flowing current affected by the coriolis force shifting the sediment bodies upslope .

\section{Indication for fluid accumulation}

Of note is the relative enhanced amplitude of the top part of the sigmoidal reflector in the seismic unit $\mathrm{Bb}$ (Fig. 9). A few of these enhanced amplitudes have a polarity inversion on the sparker seismic profiles. Instantaneous frequency analysis of a selected seismic profile, show absorption of higher frequencies below the enhanced reflection. The polarity inversions, the absorption of higher frequencies and the enhanced amplitude of the reflectors are indirect indications for fluid (gas) accumulation. Nevertheless, the reflectors below this enhanced reflector are not completely wiped out and do not show a significant loss of amplitude as should be expected if fluids were accumulating in the top of the sigmoidal structures. If fluids are accumulated in the top part of the sigmoidal bodies, this might be shallow because no indications for fluid migration have been observed from the deeper section of the profiles. During the deposition of these high-energy sediment bodies some organic matter could be trapped and produce biogenic gas that accumulated in the top of the sigmoidal forms. 


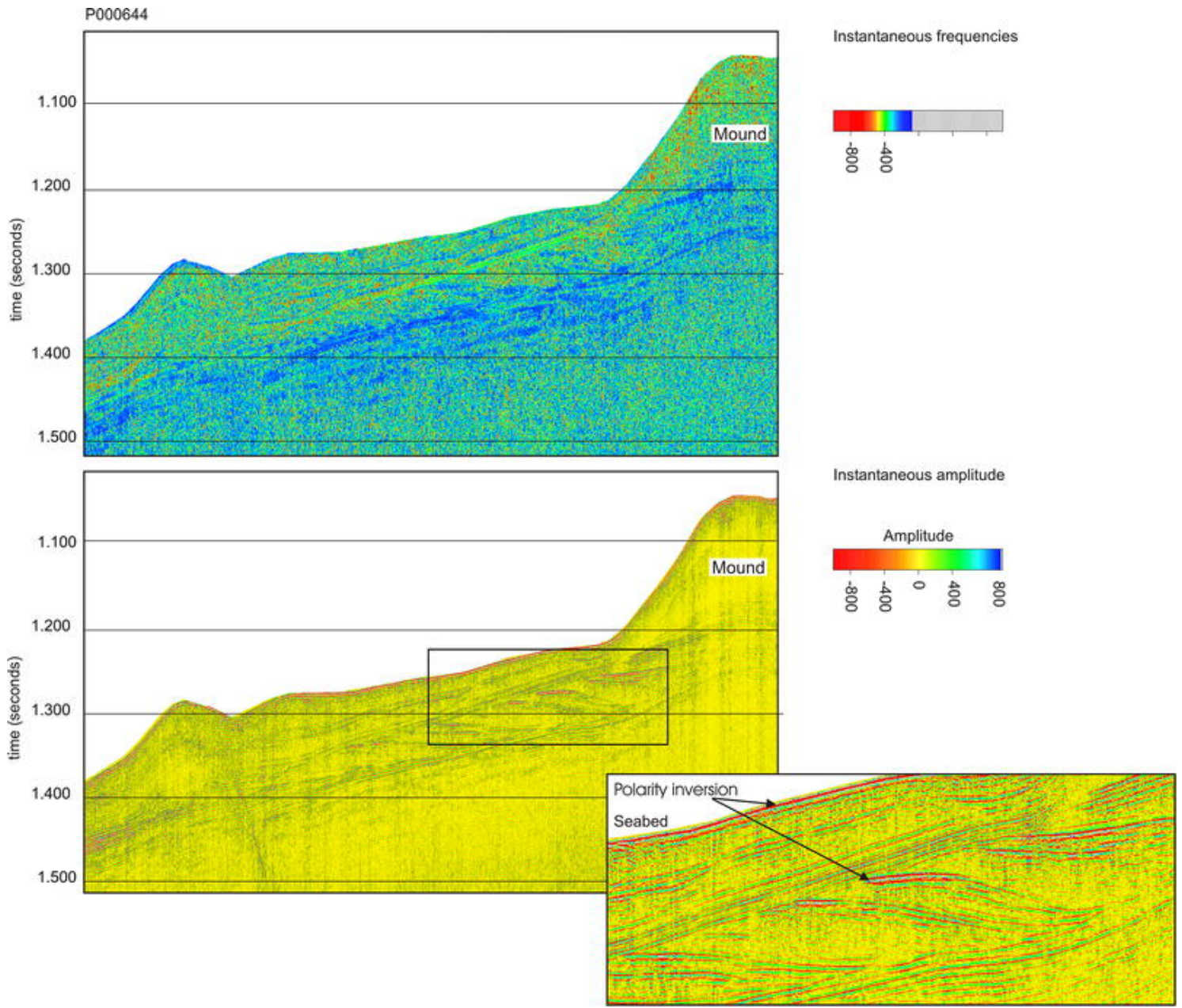

Fig. 9 Seismic attribute plots of profile P000644 Fig 8b. Instantaneous frequency plot shows absorption of higher frequencies below enhanced reflections. Amplitude analysis show enhancement of the top reflectors of the sigmoidal units, some of the reflectors show a polarity inversion but this is not found throughout the entire dataset

An alternative explanation for the phenomenon is a contrast in lithology between the top of the sigmoidal bodies and the overlying sediments in combination with the geometry of the unit, which enhanced the amplitude of the reflection.

The top reflectors of this unit might consist of more compact sediments or a diagenetic cap creating the observed higher amplitudes. No correlation is seen between mound distribution and the location of the enhanced reflectors.

\section{Present environment}

The analysis of side-scan sonar imagery combined with video interpretations illustrate the ongoing sedimentary processes on and near the mounds (Fig. 10). Side-scan sonar imagery shows the distribution of the seabed structures, which are, in this area, dominated by sediment waves. Sediment 
waves are observed in between mounds and on the lower mound's flanks varying in shape and size from $5 \mathrm{~m}$ to $50 \mathrm{~m}$ in wavelength and from $1 \mathrm{~m}$ to $10 \mathrm{~m}$ in wave height. The dimensions of the sediment waves observed on the mound flanks range between 10-15-m wavelength and $1-5-\mathrm{m}$ height with orientation of the sediment waves following the contours of the mound (Fig. 10).
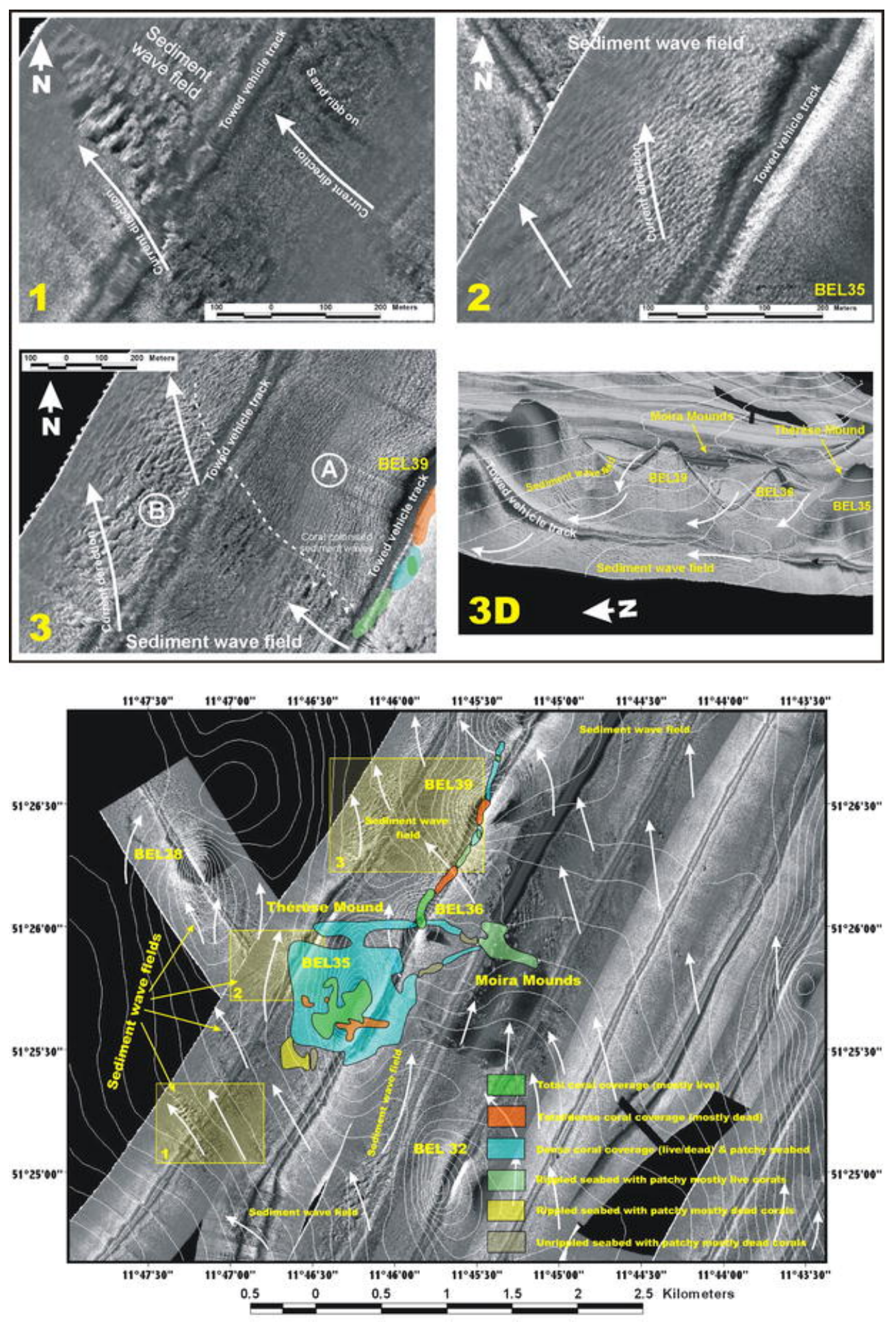

Fig. 10 High-resolution $100 \mathrm{kHz}$ side-scan sonar coverage of the Thérèse Mound study area, obtained during Discovery 248 cruise 2000 (C University College Cork). White arrows indicate bottom current direction derived from the bedforms interpretation. Transparent colourful layers show interpretation of 
underwater video imagery (SHRIMP dives 13877\#1, 13876\#1: Discovery 248 cruise; ROV Victor dives 123, 124\& 125: CARACOLE cruise 2001), legend provided. Transparent yellow boxes (1 to 3 ) outline areas of the sediment waves development that are presented in more detail on Fig. 10a a1-3: $100 \mathrm{kHz}$ side-scan sonar highlight images (see outline boxes on Fig. 10 numbered 1 to 3 ) illustrating sediment wave fields in the vicinity of the Thérèse Mound. White arrows indicate bottom current direction. Straight parallel lines running across the images are artefacts of the remote vehicle tracks. See text for details. 1 These bedforms indicating northwestern sediment transport in the $\mathrm{CH}$ channel to the southwest of BEL35. High backscatter spots on wave crests are probably caused by bio-accumulations (corals and associated fauna). 2 Sediment waves are formed by accelerated current flow, funnelled through the relatively narrow opening between the mounds. 3 Sediment wave field extending from western slope of BEL39 to the adjacent seabed. Colourful layers in the lower right of the image represent types of coral populations on BEL39 derived from video data (see Fig. 10). Two sediment wave fields (a \& b) characterised by different wave morphology are identified. The characteristics of $\mathbf{b}$ implies stronger and more turbulent currents flowing over sediment wave field $\mathbf{b}$ than over $\mathbf{a}$ on the lee side (western slope) of the mound. Accelerated current flow in B is formed due to funnelling of the northerly flowing water masses through narrow openings between BEL35/BEL36 and BEL36/BEL39. Some of the sediment waves show rubblely texture indicative of coral colonisation. 3D A 3D prospective of the study area viewed from the northwest, showing the current-topography interactions expressed by type and distribution of bedforms on the seabed (sediment wave fields on mound flanks and in between the mounds)

The sediment waves in between the mounds can be grouped into fields (Fig. 10). An extensive sediment wave field is located just to the west of BEL32 with a wavelength of $10-50 \mathrm{~m}$. The sediment wavelength in this field is smallest in between BEL32 and BEL35 (wavelength averaging $15 \mathrm{~m}$ ) and increase again in the area to the west of BEL35 to $10-20 \mathrm{~m}$. In the $\mathrm{CH}$ channel, to the south-west of Thérèse Mound (BEL35), sediment waves are present with wavelengths up to $35 \mathrm{~m}$ following the bathymetric contours of the channel, with a wave ridge orientated approximately NE-SW indicating a NW current direction in the CH channel (see Fig. 10a: 1).

Sediment waves are also observed on the southern to southwestern flanks of the mounds BEL35, BEL38 and BEL39, with wavelength varying between $7 \mathrm{~m}$ and $12 \mathrm{~m}$ (Fig. 10a: 2, 3D). This observation suggests that in the general northerly current regime the mounds act as obstacles, resulting in the sediment wave development on the mounds flanks.

In between the mounds, the dimension of the sediment waves increases up to $30 \mathrm{~m}$ in wavelength, due to current acceleration in between BEL36/39 and NE of BEL39. Sediment waves to the west of BEL39 can be divided into two fields (A\& B, see Fig. 10a: 3). Sediment waves in the field A show mainly linear crest alignment with the average wavelength of 5-7 $\mathrm{m}$, opposed to waves in 
the field B that demonstrate wavy crests with obvious bifurcation and a wavelength varying from $10 \mathrm{~m}$ to $25 \mathrm{~m}$. This implies stronger and more turbulent currents flowing over sediment wave field B then over the field A on the lee side of BEL39. Acceleration of the current flowing over field B occurs due to the funneling of the northerly flowing water masses through narrow openings between BEL35/BEL36 and BEL36/BEL39.

The changes in the sediment wave pattern clearly demonstrate a relationship between the local seabed topography and the occurrences of the mounds. All seabed structures indicate a predominately northward flowing bottom current up to $100 \mathrm{~cm} / \mathrm{s}$ facilitating active sediment transport.

To the east of the Thérèse Mound (BEL35\& BEL36), small circular shaped features can be observed within the area of sediment wave development. These features are tens of meters across (10-50 m), a few meters high and possess a "lumpy" surface structure with spots of high backscatter (Fig. 10). They were called Moira Mounds (Wheeler et al. 2001, 2005; Kozachenko et al. 2002, 2003 ) and, as has been shown by video evaluations, appear in areas of active sand transport on rippled sand sheets between the giant Belgica Mounds (Fig. 10a: 3D). Some of the Moira Mounds are elongated in the direction of the predominant northern orientated current flow, forming an ovoid plan.

\section{Biological and facies analysis}

Video imagery has been interpreted to determine biotic and abiotic seabed components and help truth the side-scan sonar and seismic surveys. Facies analysis was applied to emphase changes in the distribution of corals, coral abundance (live/dead; total/patchy) on the mounds and mound flanks, and type of seabed in the surveyed areas (e.g. rippled/unrippled sands). A single video line was run across BEL39 and BEL36, while BEL35 (Thérèse Mound) was the subject to a detailed video survey. The interpretation of the video lines is summarised in Fig. 10. Selected highlights of different facies is presented on Fig. 11. 
Total coral coverage (mostly live)
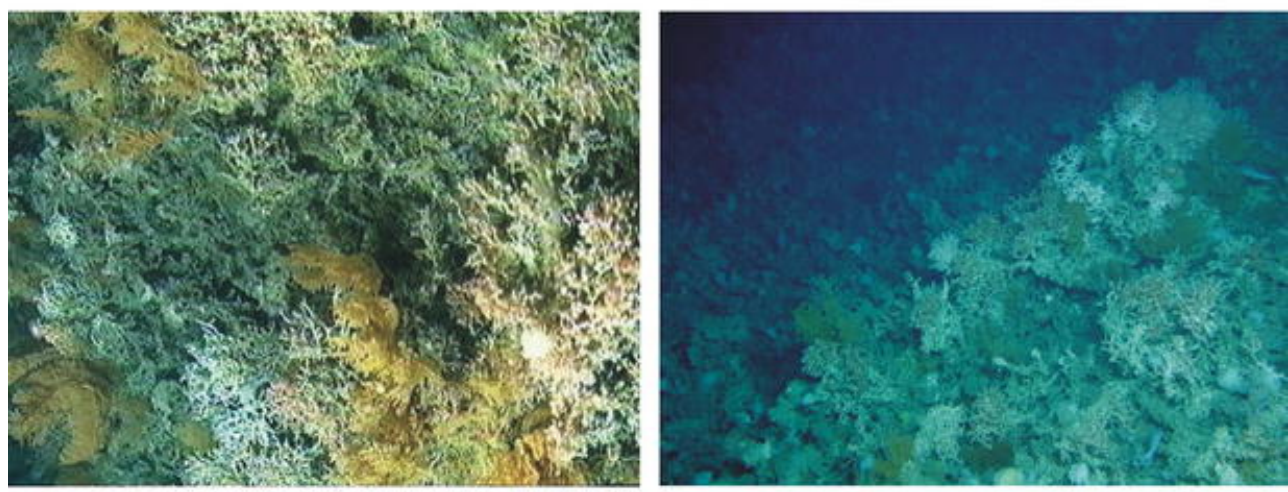

Dense coral coverage (live/dead)
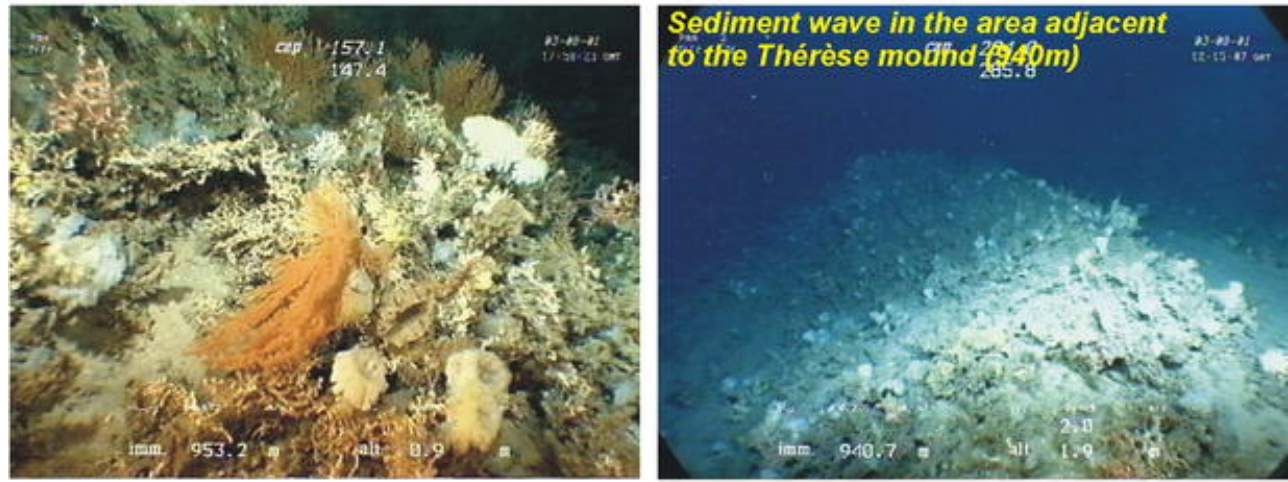

Total/dense coral cover (mostly dead)

\section{Rippled seabed \& patchy corals}
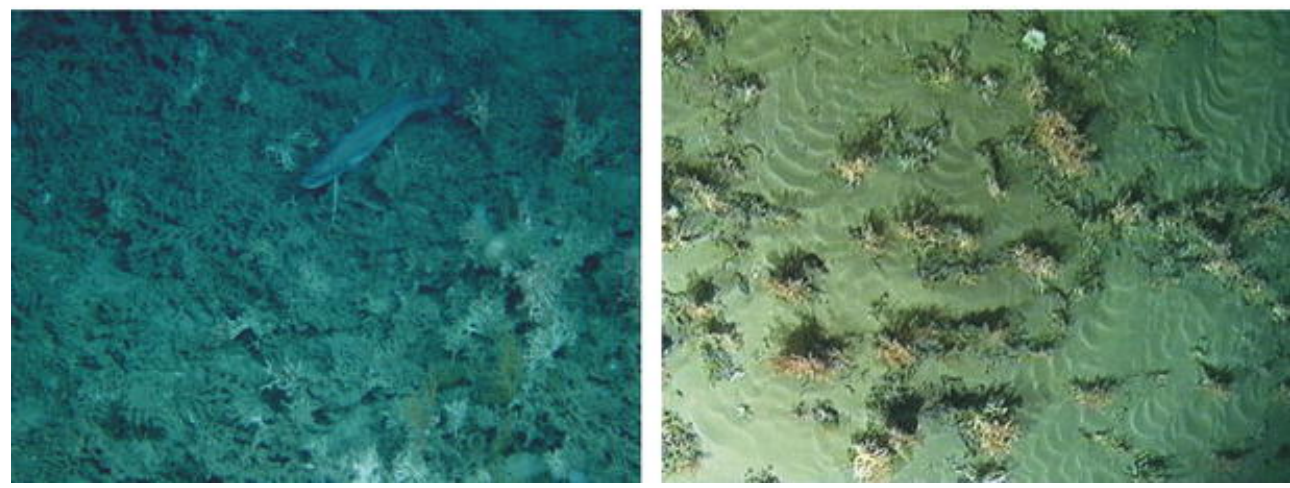

Fig. 11 Video highlights of different seabed facies in the Thérèse mound area. The geographical distribution of these seabed facies are illustrated in Fig. 10. (Images IFREMER). Height and width measurements of the mound seismic unit along seismic profiles. Grey shaded rows indicate profiles with a NNW-SSE orientation, the other ones a ENE-WSW

SHRIMP video line 13877\#1 (Fig. 10) shows that the northern slope of BEL39 is totally colonised by deep-water corals. Here, both living and dead corals represent the coral cover, but nevertheless shows near total coverage. On the top of the mound, a well-developed dead coral framework is observed that may suggest limited erosion. The southern slope, which was inferred from the seismic profiles as a buried flank, is characterised by a smooth seabed with patchy dead and living coral cover. At the base of the southern slope, where the scouring occurred, a 40-m area 
of healthy framework development with total coral cover is present. In the trough between BEL39 and BEL36, the seabed is rippled and the sediment is sandy with patchy live corals. This corresponds with the area of current acceleration as illustrated by side-scan sonar record.

The base of the northern slope of BEL36 is characterised by dense coral cover (live and dead) with patchy unrippled sediment. These facies, moving upslope is replaced by total coral cover, so that a transition from mostly dead corals at the base of the mound to mostly live coral framework development at the top of the mound is encountered.

CARACOLE video line 124 starts on the eastern flank of BEL36 in the Moira Mounds area, crossing BEL36 and then running across the northern slope of BEL35 with subsequent surveys of BEL35 in the north-south direction across its summit. The start of this survey line revealed a seabed facies showing patchy to dense coral cover on rippled seabed on top of the Moira Mounds - relatively small accumulations of living and dead coral framework, filled with sediment, and rippled seabed with occasional dropstones and patchy live corals, in places, in the areas between these small scale coral constructions. These coral constructions might illustrate the initial stage of the coral bank formation (Wheeler et al. 2001, 2005; Kozachenko et al. 2003). The Moira Mounds are enclosed between rippled sandy seabed, which gradually changes to a smooth seabed toward BEL36. Detailed facies analyses of Moira Mounds area is presented in Wheeler et al. (2005). To the west of the Moira Mounds, the dominant facies show a smooth seabed with patchy, mostly dead corals as well as dense dead and alive coral coverage with patchy seabed.

The coral cover becoming denser while moving further west and closer to BEL36. The eastern slope of BEL36 shows dense live/dead coral coverage with patchy unrippled seabed, which forms a total seabed cover on the upper flank of the mound. At the top of BEL36 where CARACOLE 124 line meets SHRIMP 13877\#1, both surveys show total coverage with a healthy coral framework development. The western slope of the mound shows dense live (with some localised subordinate dead coral evident) coral coverage with patchy unrippled seabed. This facies extends all the way to BEL35 and along the northern slope of Thérèse Mound until its top. The summit of Thérèse Mound shows healthy (mostly living) coral framework development.

The sediment waves on the eastern flank of the Thérèse Mound are well pronounced on the side-scan sonar and multibeam images. Video imagery has shown a distinct relationship to sediment waves that have become colonised and stabilised by corals and associated communities. On the edge of the BEL35, corals colonise the crests of sediment waves with limited growth in the troughs, taking advantage of stronger current and nutrient flux. Coral density increases up the mound until 
sediment waves become fully stabilised and coral continue to grow into coral banks on the mound summit (Wheeler et al. 2002, 2005).

\section{Facies distribution on Thérèse Mound (BEL35)}

The Thérèse Mound (BEL35) was surveyed during four dives: one with SHRIMP 13876\#1, and three with ROV Victor (dives 123, 124 and 125). Most of the mound surface is characterised by dense coral coverage with patchy unrippled sediment in places (Figs. 10,11). Within this facies, live corals tend to grow on top of dead coral, and therefore dead and live corals occur in nearly equal proportions. The mostly healthy live coral reef frameworks are observed on the mound summit. This facies supports an extensive epifauna of soft corals (gorgonians), sponges, and other deep marine fauna (e.g. sea stars, sea urchins, crabs, shrimps and deep-sea fish). On the southeastern flank of the mound, there is a relatively narrow area of mostly dead corals with dense coverage and patchy unrippled sediment. At the base of the mound on the southwestern flank, the dominant facies is characterised by patchy dead corals that occur on rippled seabed. Seabed truthing with the ROV shows that areas of rippled seabed are represented by sandy sediment. In the dead coral framework facies, the framework becomes clogged with sediments and dead epifauna.

\section{Discussion}

The combined results obtained with the different techniques contribute to the understanding of the coral bank development and evolution in the Belgica Mound Province. The mound structures discussed in this paper are interpreted as coral banks, based on their surficial biological, sediment samples and seismic characteristics (De Mol et al. 2002; Huvenne et al. 2002; Van Rooij et al. 2003). The geological structures underneath the mounds illustrate the difference in the environmental setting before and after the mound development. The side-scan sonar and video profiling gives insight in the potential start-up of the mound development and ongoing processes in the mound area. The results of this study support the hypothesis that the corals are the most important building blocks of the giant coral mounds in the Porcupine Seabight.

\section{Substratum}

Van Rooij et al. (2003) interpreted the different seismic facies below the mound base (R4) as sequences in a slope parallel drift under changing oceanographic conditions. The build-up of a drift body implies both erosion and deposition. Erosional features are seen as local discontinuities, 
channels, and scouring of the slope, creating local and more regional incisions in the underlying units.

From the geometry of the drift and the sigmoidal units of seismic unit Bb in the study area, an along slope (NS) bottom current is inferred. The coriolis effect deflects the flow to the right, effectively constraining the flow against the slope. Being so constrained, the flow intensifies, erosion occurs and a channel develops with the drift tending to migrate upslope. These currents seem to be dominant since the onset of the drift sequence in the Miocene (McDonnell 2001), with intervals of vigorous pulses creating erosion and slowdown of the currents with a local reorientation of the currents. The driving current seems to be focussed near the lower end of the slope as bottom currents, similar to the present-day current regime but apparently more vigorous. The base of the coral banks is the last regional erosional event before the enclosing drift sedimentation becomes installed. This erosional event is estimated to be Late Pliocene in age (De Mol 2002; De Mol et al. 2002, Van Rooij et al. 2003).

The period after the erosional event and non-deposition might be the most important period in the set-up of the coral banks. The requirements for coral growth are a hard substratum, adequate nutrient supply and protection against burial (Freiwald et al. 1999; De Mol et al. 2002; Kenyon et al. 2003). In comparison with the present-day situation, the initial coral bank nucleus might start to grow on local elevated structures on the seabed as sandwaves, erosional scars and/or sediment lag deposits. These provide the coral with a hard substratum combined with a necessary nutrient flux to stay alive and propagate. Several papers link coral bank initiation and development to the occurrences of gas or other fluid migration of the underlying geological structures (e.g. Hovland et al. 1994; Hovland and Risk 2003; Henriet et al. 1998, 2001). Nevertheless in this study, no clear evidence is found for such a relation and it seems not to be necessary for the development coral banks.

\section{Location of the coral banks}

At the present-day seafloor, the coral banks are located along relatively steep channel flanks, in zones with reduced drift sedimentation. The reduction of the sediment around the coral banks is a combined effect of the presence of the mound, creating turbulence in the water column, of slope gradients in the underlying structures and vigorous currents in the channels. Once the mounds got initialised the development continues in areas where the current was/is high enough to save the framework constructors from being buried by sediment and providing them with sufficient nutrients. The most suitable places seem to be on local slopes on the mound base created by erosion or by 
the underlying geological sequences, or on elevated seabed structures such as sand waves, dropstone or lag deposits. Alternative sites are on the flat seafloor in the current flow of the contour current as in the case of BEL38.

\section{Mound morphology}

It seems that in the most ideal conditions (available space, reduced sedimentation, good balance of currents), the coral banks developed more or less circular in plan view.

However, in the surface expression all mounds show a more or less NS elongated shape due to the accumulation of sediments on the flanks. This illustrates that the present-day bathymetry does not present the full mound geometry, which includes buried components. The elongated coral banks are located at the edge of the channels and are formed parallel to the channel flank. The seabed morphology and related oceanographic processes seem to dictate coral bank development.

\section{Biology}

One of the most important observations is the intense colonization by a benthic community on Thérèse Mound (BEL35). The present-day biozonation of the epibenthic life and the surface sediment fauna gives an insight into sediment processes ongoing on the flanks of the mound. These processes are used as a key to the past development of the mound.

The results of the biozonation of the coral banks illustrates that living corals and associated fauna are localised on the steep flanks facing local depressions or at the stoss side of the coral banks. At the foot of the steep flanks, where the slope gradient decreases, less living fauna is observed coincident with high sediment stressing.

Side-scan sonar coverage implies that the morphology of the Thérèse Mound and surrounding seabed is strongly dictated by prevailing basal current activity (Figs. 10, 11). This has been confirmed by video observations during ROV dives. The surface morphological details of the Thérèse Mound show distinct relationships to sediment waves that have become colonised by coral and associated communities. On the edge of the mound, corals colonise the crests of sediment waves with limited growth in the troughs, therefore taking advantage of stronger current and nutrient flux. If this process is ongoing the coral density increases until the sediment waves become fully stabilised and coral continue to grow into coral banks. 


\section{Baffling of sediment}

A dead coral framework is observed just below the living coral zone colonised by a different benthic community than in the living zone. Further down the slope of the mounds, the coral framework becomes progressively filled with sediment and the macrobiotic fauna reduces. The baffling of sediments by the coral framework supports the framework and strengthens the construction. In zones where the sediment supply is high enough to completely fill the coral framework, a smoothed flank with a gentle slope is encountered. If the currents are strong enough to keep the sediment in suspension or when the sediment supply is reduced, the coral framework stays exposed or grows in pace with the baffling of sediments in the framework. Such flanks of stacked coral colonies create steep slopes on the upper mound flanks and on the top of sand waves, e.g. on the Moira Mounds.

\section{Currents}

Several observations argue that the coral banks are closely related to high current regimes. The formation of NS trending contourite channel and contourites indicate a long-term northerly flowing current (Van Rooij et al. 2003). The coral banks take advantage of the high current regime, related nutrient flux and the reduced of sediment deposition of deep NS orientated channel. Sand ripples and sand sheets around and in between the mounds illustrate the local turbulence around the mounds, with current speeds up to $1 \mathrm{~m} / \mathrm{s}$. Depressions along the mounds are interpreted as scouring structures created by current and a reduction of sedimentation. The colonisation of benthic suspension feeders, corals and sponges take advantage of the higher current regime and contribute to the development of the coral bank as solid constructions.

The enhancement of the currents in this particular zone of the Porcupine Seabight is related to the interaction of the seabed topography and the stratification of water masses (De Mol et al. 2002; Van Rooij et al. 2003). Similar observations are made in the Rockall Trough where giant carbonate mud mounds occur in zones with high current velocities and at the level of nepheloid layers proving food to the coral accumulations (Kenyon et al. 2003).

\section{Conclusion}

This case study of Thérèse Mound and adjacent mounds is the most detailed study of coral banks in the Porcupine Seabight. The results gathered by various techniques shed light on the ongoing processes on the coral banks and the preferential environmental settings for coral bank construction. 
- The location of coral bank development seems to be related to local topographic features. The coral banks started to develop near erosive scarps of the mound base reflector R4 created by the underlying sigmoidal drift sequences at the Late Pliocene-Quaternary boundary.

- No preferential substratum is found, neither is there an indication for a deep geological control of the coral bank development.

- The possible initial phase of coral bank development is the colonisation of local seabed structures, such as lag deposits, local slopes, sand waves, that provide the coral with a hard substratum, place them higher in the water column protecting them of burial and allowing the corals to benefit from faster flowing (higher nutrient flux) water regimes.

- Initial coral bank development, during the period of non-deposition or low sedimentation, created a broad base. In the later phases the coral banks kept pace with the sedimentation and developed in a vertical direction.

- The coral bank morphology is influenced by the local current regime and surrounding seabed morphology.

- Sediments accumulated on the eastern flanks of the coral banks or upslope due to weaker current speeds and a dominating sediment source from the shelf.

- The coral bank initation and development is closely related to the drift sedimentation and influence of currents, sedimentation rates and the local morphology of the mound base and the present seabed.

Acknowledgements This study is based on the results of the EU FP5 research projects GEOMOUND, ECOMOUND, ACES and EURODOM of the OMARC cluster. We wish to thank the Management Unit of the Mathematical Model of the North Sea (MUMM) of Belgium for providing ship time on RV Belgica. The captain and crew of the RV Belgica, RRS Discovery and RV L'Atalante are thanked for their support at sea. The authors would also like to acknowledge the Scientific Parties of Belgica-Porcupine 97, 98, 99, 2000, RV Polarstern 2000, Discovery 248 and CARACOLE campaigns.

\section{References}

Bett BJ, Billett DSM, Masson DG, Tyler PA (2001) RRS Discovery Cruise 248, 07 Jul - 10 Aug 2000. A Multidisciplinary Study of the Environment and Ecology of Deep-Water Coral Ecosystems and Associated Seabed Facies and Features (the Darwin Mounds, Porcupine Bank and Porcupine Seabight). Southampton Oceanography Cruise Report No. 36

Beyer A, Schenke HW, Klenke M, Niederjasper F (2000) High Precision Multibeam Survey of a Carbonate Mound Area in the Porcupine Basin. EOS 81(41):F638 
Beyer A, Schenke HW, Klenke M, Niederjasper F (2003) High Resoultion Bathymetry of the Eastern Slope of the Porcupine Seabight. Marine Biology 198:27-54

Beyer A et al. (2003) Seafloor study of the Eastern slope of the Porcupine Seabight using multibeam bathymetry and backscatter

Olu-Le Roy K, Caprais J-C, Crassous P, Dejonghe E, Eardley D, Freiwald A, Galeron J, Grehan A, Henriet J-P, Huvenne V, Lorance P, Noel P, Opderbecke J, Pitout C, Sibuet M, Unnithan V, Vacelet J, Van Weering T, Wheeler A, Zibrowius H (2002) CARACOLE Cruise Report. 30/07/2001 (Cobh) - 15/08/2001 (Foynes) N/O L'Atalante\& ROV VICTOR, Vols 1\& 2. Unpublished Report, IFREMER, Brest

De Mol B (2002) Development of coral banks in Porcupine Seabight (SW Ireland) A multidisciplinary approach. PhD Thesis, Ghent University, Ghent, 363-175 appendix)

De Mol B, Van Rensbergen P, Pillen S, Van Herreweghe K, Van Rooij D, McDonnell A, Huvenne V, Ivanov M, Swennen R, Henriet JP (2002) Large deep-water coral banks in the Porcupine Basin, southwest of Ireland. Mar Geol, p 188

Freiwald A, Wilson JB, Henrich R (1999) Grounding Pleistocene icebergs shape recent deep-water coral reefs. Sedimentary Geology 125:1-8

Galanes-Alvarez H (2001) A pseudo 3D very high resolution seismic study of the Therese mound, Porcupine Basin, offshore SW Ireland. MSc-Thesis Thesis, University of Wales, Bangor, p 114

Henriet J-P, De Mol B, Pillen S, Vanneste M, Van Rooij D, Versteeg W, Croker PF, Shannon PM, Unnithan V, Bouriak S, Chachkine P, Party TP-BS (1998) Gas hydrate crystals may help build reefs. Nature 391:648-649

Henriet JP, De Mol B, Vanneste M, Huvenne V, Van Rooij D, The "Porcupine-Belgica" 97, a.s.p. (2001) Carbonate mounds and slope failures in the Porcupine Basin: a development model involving past fluid venting. In: Shannon PM, Haughton P, Corcoran D (eds) Petroleum Exploration of Irelands's Offshore Basins. Special Publication Geological Society of London, London, pp 375-383

Henriet JP, De Mol B, Dullo W-C, Freiwald A, Joergensen BB, Parkes J, Patching JW (1999) Modern Carbonate Mounds: Porcupine Drilling. ODP-proposal, p 573

Hovland M, Croker PF, Martin M (1994) Fault-associated Seabed Mounds (Carbonate Knolls?) off Western Ireland and North-west Australia. Mar Petrol Geol 11(2):232-246

Hovland M, Risk M (2003) Do Norwegian deep-water coral reefs rely on seeping fluids? Mar Geol 198:83-96

Huvenne V, Blondel P, Henriet JP (2002) Textural analyses of sidescan sonar imagery from two mound provinces in the Porcupine Seabight. Mar Geol 189:323-341

Kozachenko M, Wheeler AJ, Beyer A, Blamart D, Masson D, Olu-Le Roy K (2003) Ireland's Deep-Water Coral Carbonate Mounds: Multidisciplinary Research Results, Abstract, EGS - AGU - EUG Joint Assembly, Nice, France, April 2003

Kozachenko M, Wheeler A, Beyer A, Blamart D, Masson D, Olu-Le Roy K (2002) A four dimensional prospective of the sedimentary processes and their interactions with Ireland's deep-water coral carbonate mound ecosystems: Belgica Carbonate Mound province, Eastern Porcupine Seabight, NE Atlantic', Geophysical Research Abstracts, Volume 4, 2002, Abstract number: EGS02-A-02529, 27th General Assembly of the European Geophysical Society, Nice, 21-26 April 2002

Kenyon N, Akhmetzhanov AM, Wheeler AJ, van Weering TCE, de Haas H, Ivanov MK (2003) Giant Carboante Mud Mound in the Souther Rockall Trough. Mar Geol

Le Bas, Huhnerback V (1999) PRISM: Processing of Remotely-sensed Imagery for Seafloor Mapping. Southampton Oceanography Centre, Unpublished: p 82

Le Danois E (1948) Les profondeurs de la mer. Payot, Paris, p 303

Mc Donnell A (2001) Comparitive Tertiary basin Development in the Porcupine and Rockall ABsins. $\mathrm{PhD}$-thesis Thesis, National University of Ireland, Dublin

Thomson CW (1873) The depths of the Sea. MacMillan, London, p 527

Van Rooij D, De Mol B, Huvenne V, Ivanov M, Henriet JP, (2003) Seismic evidence of current-controlled sedimentatiion in the Belgica mound provicne, southwest of Ireland. Mar Geol 195:31-53

Wheeler A, Kozachenko M, Beyer A, Huvenne VAI, Masson D, Olu-Le Roy K (2005) Sedimentary Processes and Carbonate Mound Morphology: The Belgica Mounds, Porcupine Seabight, NE Atlantic. In: Freiwald 
A, Roberts JM (eds) Proceedings of the 2nd international symposium on deep-water corals, Springer, Berlin Heidelberg New York

Wheeler AJ, Bett BT, Billett DSM, Masson DG, Scientific Party, Officers \& Crew of RRS Discovery 248 (2000) High Resolution Side-scan Sonar Mapping of Deep-Water Coral Mounds: Surface Morphology and Processes Affecting Growth. In: 2000 Fall Meeting December 15-19, 2000 San Francisco, California; Published as a supplement to EOS, Transactions, American Geophysical Union, Vol. 81, No. 48

Wheeler A, Kozachenko M, Sutton G (2001) An Atlas of Side-scan Sonar Imagery of Deep-water Coral Bioherms\& Related Seabed Features, NE Atlantic, Deliverable Report for Atlantic Coral Ecosystem Study (ACES) project: $\mathrm{p} 220$ 


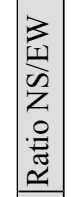

용

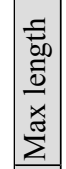

$\equiv \quad \overline{\underline{a}}$

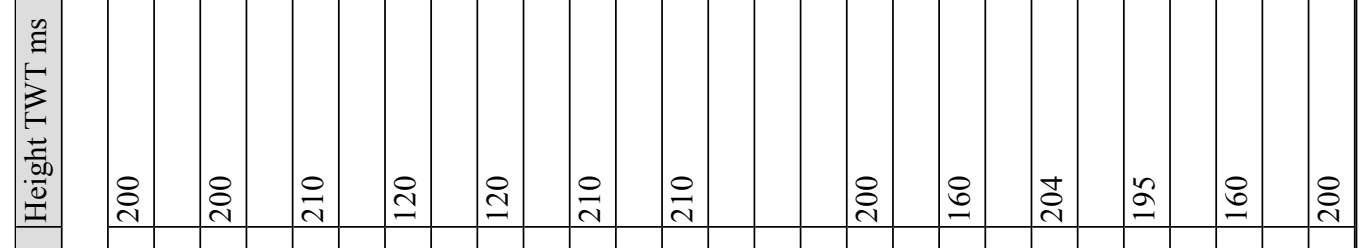

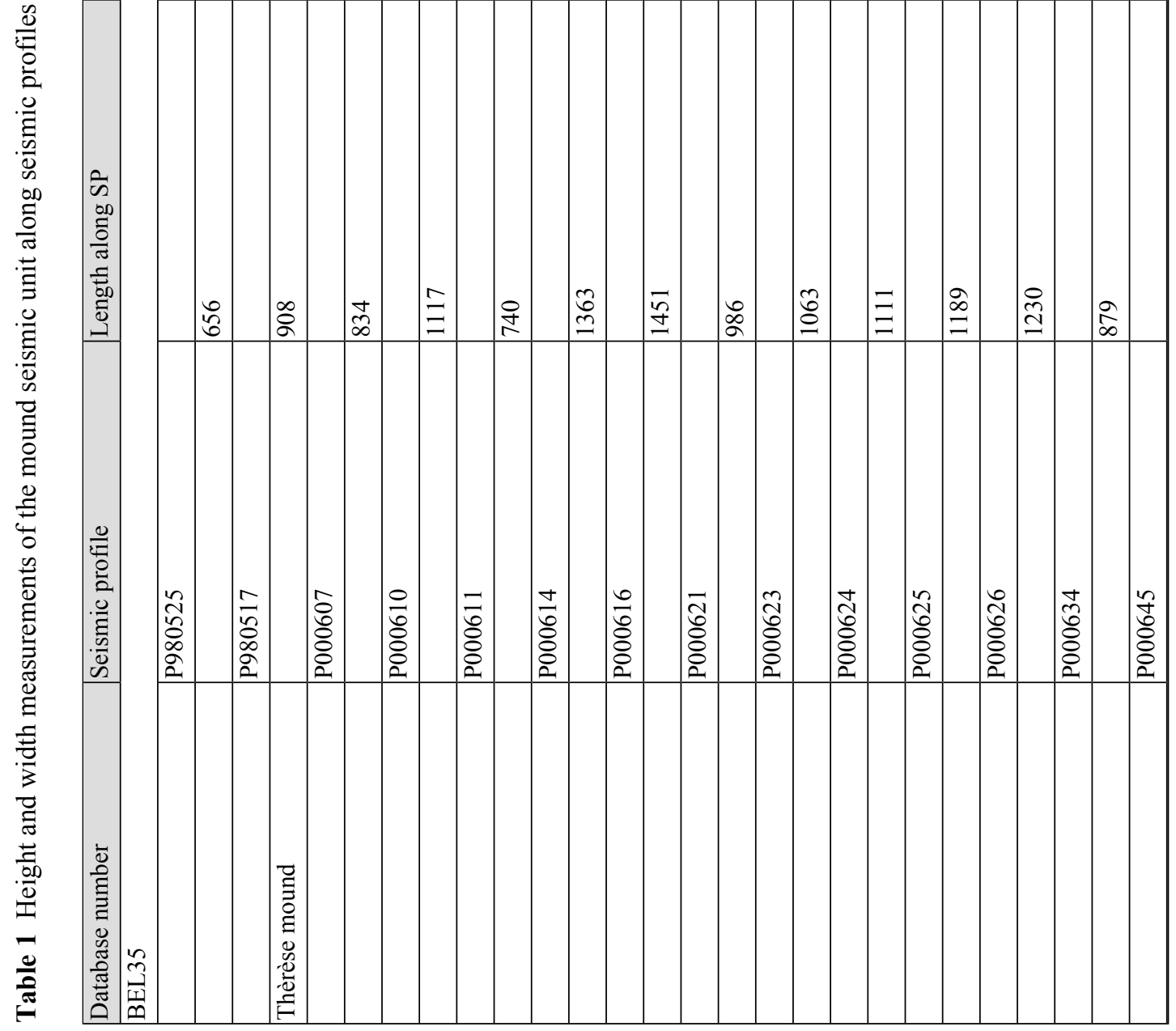




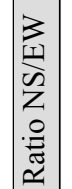

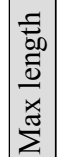

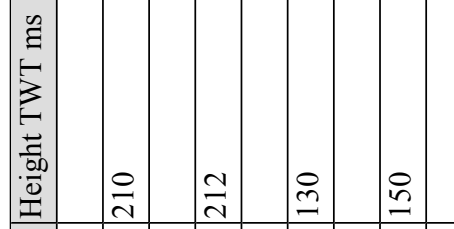

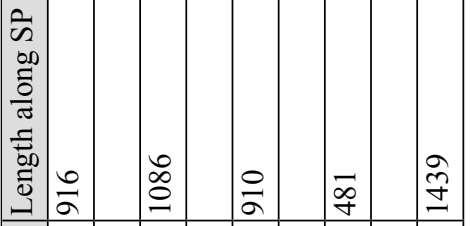

ชู

$\underset{\infty}{\bar{\infty}}$

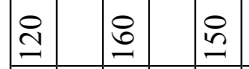

욤ำ

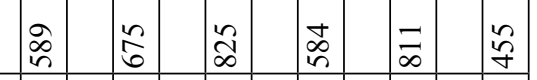

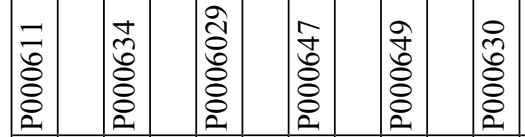

吕

吉

$\therefore \quad ? \quad \stackrel{\infty}{=}$

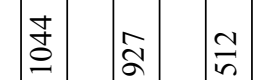

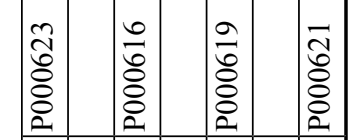




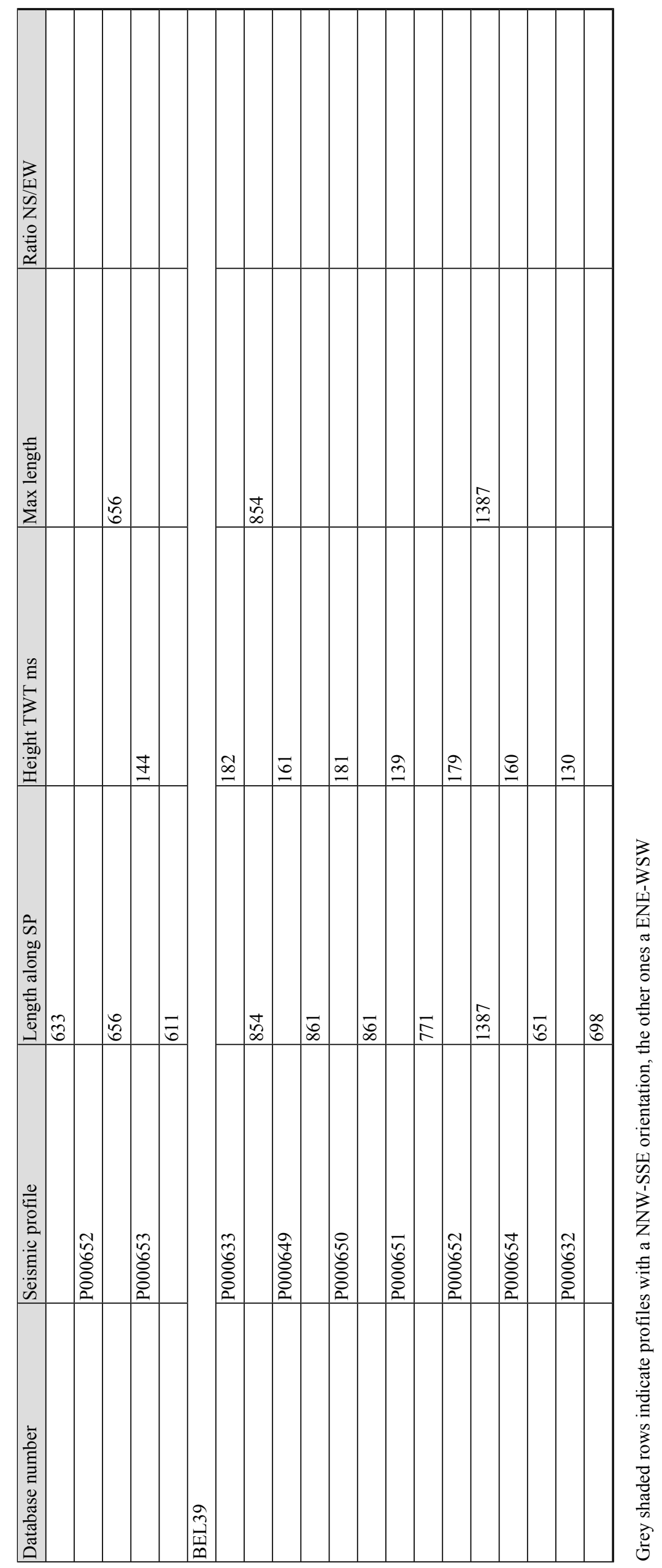

